\title{
Иммуноцитофит на томатах открытого грунта
}

\section{О.В. Коробейникова, В.М. Мерзлякова}

В условиях Удмуртской Республики изучали влияние опрыскивания томата регулятором роста растений Иммуноцитофит на урожайность и пораженность болезнями. В результате применения Имуноцитофита отмечено увеличение урожайности томата детерминантных сортов, предназначенных для открытого грунта Ляна и Грот. Опрыскивание Иммуноцитофитом существенно снижало пораженность томата вершинной гнилью и фитофторозом.

Ключевые слова: томат, открытый грунт, детерминантные сорта, Ляна, Грот, регуляторы роста растений, Иммуноцитофит, урожайность, пораженность болезнями, неинфекционная вершинная гниль, фитофтороз.

сухие, жаркие годы на дерновоподзолистых почвах Удмуртии томатам не хватает влаги и кальция, в результате они поражаются неинфекционной вершинной гнилью. При избыточном количестве осадков томаты уже в июле могут быть поражены фитофторозом. Поэтому, в наших условиях семена сеют в конце февраля - начале марта, высадка рассады в открытый грунт - в начале июня (до 10 июня имеется риск заморозков). В августе плоды уже бывают поражены фитофторозом. В итоге урожай собирают в июле, и очень многие садоводы-любители собирают зеленые плоды, а затем закладывают их на дозаривание.

Изучением технологии возделывания и сортов томатов в условиях Удмуртии занимаются сотрудники ФГБОУ ВО Ижевская ГСХА Е.В. Соколова, В.М. Мерзлякова, М.А. Лебедева, Т.Н. Тутова и др. [1, 2].

В течение нескольких лет авторы исследовали влияние биологического фунгицида Фитоспорин-М [3] и регулятора роста растений Иммуноцитофит на урожайность и пораженность томатов открытого грунта болезнями.

Цель исследований: оценкаэффективности препарата Иммуноцитофит на томатах (влияние на пораженность растений болезнями).

Исследования на томатах сортов Ляна и Грот проводили в условиях АО «Учхоз Июльское Ижевской ГСХА» Воткинского района Удмуртской Республики с 2012 по 2016 годы. Опыт двухфакторный (фактор А - сорта томата, фактор В - опрыскивание препаратом Иммуноцитофит), проводили в четырехкратной повторности систематическим методом [4].

Метеорологические условия в годы проведения исследований были различными: 2013 и 2016 годы были сухими и жаркими (ГТК $=0,7)$; 2012, 2014 и 2015 годы- холодными и дождливыми (ГТК = 1,6 и 1,5, соответственно). Почвы дерново-подзолистые среднесуглинистые слабосмытые. Содержание гумуса среднее; слабокислые, содержание подвижного фосфора очень высокое, обменного калия высокое. Сорт Ляна включен в Государственный реестр селекционных достижений в 1996 году по многим регионам и предназначен для открытого грунта. Раннеспелый, детерминантный, дружносозревающий сорт, салатного назначения. Плоды округлые, гладкие, ярко-красные, плотные, массой 65-83 г. Вкусовые качества хорошие [5].

Таблица 1. Влияние Иммуноцитофита на урожайность томата сортов Ляна и Грот (среднее за 2012-2016 годы)

\begin{tabular}{|c|c|c|c|c|c|c|}
\hline \multirow{3}{*}{ Вариант (фактор В) } & \multicolumn{2}{|c|}{$\begin{array}{l}\text { Количество } \\
\text { плодов, шт. }\end{array}$} & \multicolumn{2}{|c|}{ Масса плода, г } & \multicolumn{2}{|c|}{$\begin{array}{l}\text { Урожайность, } \\
\text { кг/M² }\end{array}$} \\
\hline & \multicolumn{6}{|c|}{ сорт (фактор A) } \\
\hline & Ляна & Грот & Ляна & Грот & Ляна & Грот \\
\hline $\begin{array}{l}\text { Контроль (без опрыскивания } \\
\text { растений) }\end{array}$ & 26 & 36 & 52 & 55 & 4,1 & 5,9 \\
\hline $\begin{array}{l}\text { Опрыскивание растений } \\
\text { Иммуноцитофитом }\end{array}$ & 34 & 39 & 55 & 61 & 5,6 & 7,1 \\
\hline $\mathrm{HCP}_{05}$ по фактору A & \multicolumn{2}{|c|}{7} & \multicolumn{2}{|c|}{$\mathrm{F} \phi<\mathrm{FT}$} & \multicolumn{2}{|c|}{0,9} \\
\hline по фактору В & \multicolumn{2}{|c|}{7} & \multicolumn{2}{|c|}{3} & \multicolumn{2}{|c|}{0,9} \\
\hline частных различий & \multicolumn{2}{|c|}{10} & \multicolumn{2}{|c|}{5} & \multicolumn{2}{|c|}{1,3} \\
\hline
\end{tabular}

Сорт Грот включен в Госреестр в 1994 году по Волго-Вятскому региону. Раннеспелый, детерминантный, засолочный сорт. Плоды округлые, плотные, в незрелом состоянии имеют темное зеленое пятно у плодоножки, в зрелом - красные. Масса плода 60-80г [5].

Иммуноцитофит (д.в.- этиловый эфир арахидоновой кислоты 0,167 г/ кг). Арахидоновая кислота - гормоноподобное вещество, вызывающее у растений защитную реакцию с выделением стрессовых метаболитов, и обладающая благодаря этой реакции рострегулирующими свойствами [6]. Препарат зарегистрирован с 1997 по 2021 год. Предназначен для повышения устойчивости к болезням, неблагоприятным погодным условиям и вредителям, ускорения роста и развития растений, созревания плодов, улучшения вкусовых и питательных качеств овощей и фруктов, снижения потерь урожая при хранении [7].

Ранее в исследованиях, проведенных в ФГБОУ ВО Ижевская ГСХА, выявлено положительное действие Иммуноцитофита на увеличение урожайности и снижение пораженности болезнями на яровой пшенице и ячмене [8]. Действие Иммуноцитофита на растения томата изучали и в СГАУ имени Вавилова. Выявлено, что Иммуноцитофит ускорял рост растений, наступление фазы цветения и плодообразования, способствовал увеличению количества и массы плодов, снижал поражаемость томатов фитофторозом, септориозом, вершинной гнилью, бактериозом [9].

Опрыскивание Иммуноцитофитом проводили через неделю после высадки рассады в грунт в соответствии со «Списком пестицидов и агрохимикатов, разрешенных к применению на территории Российской Федерации» [10]. Первое опрыскивание - в фазу бутонизации, второе и третье оп- 
Таблица 2. Влияние опрыскивания растений Иммуноцитофитом на распространенность болезней на плодах (2012-2016 годы)

\begin{tabular}{|c|c|c|c|c|}
\hline \multirow{3}{*}{ Вариант (фактор В) } & \multicolumn{2}{|c|}{$\begin{array}{c}\text { Фитофтороз,\% среднее за } \\
\text { 2012-2015 годы }\end{array}$} & \multicolumn{2}{|c|}{$\begin{array}{c}\text { Вершинная гниль, \% } \\
\text { среднее за } 2013 \\
\text { и } 2016 \text { годы }\end{array}$} \\
\hline & \multicolumn{4}{|c|}{ сорт (фактор A) } \\
\hline & Ляна & Грот & Ляна & Грот \\
\hline $\begin{array}{l}\text { Контроль (без опрыскивания } \\
\text { растений) }\end{array}$ & 16,8 & 29,7 & 12,0 & 9,3 \\
\hline $\begin{array}{l}\text { Опрыскивание растений } \\
\text { Иммуноцитофитом }\end{array}$ & 5,8 & 24,7 & 8,8 & 5,9 \\
\hline $\mathrm{HCP}_{05}$ по фактору A & \multicolumn{2}{|c|}{8,2} & \multicolumn{2}{|c|}{2,9} \\
\hline по фактору В & \multicolumn{2}{|c|}{8,2} & \multicolumn{2}{|c|}{2,9} \\
\hline частных различий & \multicolumn{2}{|c|}{11,5} & \multicolumn{2}{|c|}{4,1} \\
\hline
\end{tabular}

рыскивание - в фазу цветения первой и третьей кисти соответственно. Норма расхода препарата 1 таб. (0,3 г) на 1,5 л воды. Расход рабочей жидкости 1,5 л/50 м².

Сбор плодов - трижды за вегетацию. В результате применения Иммуноцитофита увеличилась урожайность обоих сортов. Прибавка урожая на сорте Ляна составила 1,55 кг/ $\mathrm{M}^{2}$, на сорте Грот 1,20 кг/м² (табл. 1). Прибавка урожая произошла за счет увеличения количества плодов на 8 шт. (сорт Ляна) и увеличения массы плода (на обоих сортах) на 3 и 6 г соответственно. Масса плода в контроле на сорте Ляна составила 52 г, на сорте Грот 55 г. Существенной разницы между массой плодов на исследуемых сортах при проведении статистической обработки не отмечено (Fф<Fт).

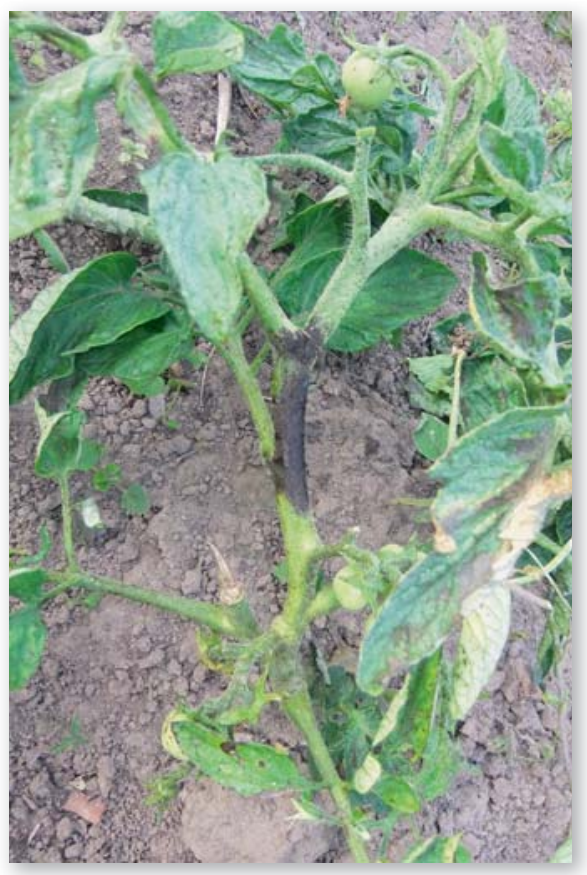

Растения томатов, пораженные фитофторозом (2015 год)
Урожайность товарных плодов томата в большой степени зависит от пораженности болезнями. В опыте наблюдались вершинная гниль и фитофтороз (табл. 2).

Пораженность болезнями зависела от метеорологических условий. Массовое развитие фитофтороза в дождливые и прохладные 2014 и 2015 годы наблюдалось уже с середины июля. В 2012 и 2013 года в августе. В жаркий, засушливый 2016 год фитофтороз не наблюдался. Существенное снижение количества пораженных плодов под действием Иммуноцитофита в среднем за четыре года отмечено только на сорте Ляна на $11 \%$.

Вершинная гниль плодов отмечалась в 2013 и 2016 году, что было связано с отсутствием осадков и жаркой погодой во время созревания. Полив не спасал растения от вершинной гнили, так как почва была очень сильно пересушена и влага не доходила до корней. В то же время, опрыскивание вегетирующих растений Иммуноцитофитом способствовало существенному снижению количества больных плодов на обоих сортах, вероятно, за счет увеличения антистрессовой активности растений.

В 2013 году на томатах появилась томатная совка - карадрина, которая выгрызала в листьях крупные дырчатые отверстия, а также внедрялась внутрь плодов. Различий между необработанными и обработанными Иммуноцитофитом растениями не наблюдалось.

Таким образом, применение регулятора роста растений Иммуноцитофит в виде опрыскивания растений томата способствовало повышению урожайности исследуемых сортов, предназначенных для выращивания в открытом грунте в условиях Удмуртской Республики и снижению пораженности их фитоф- торозом на сорте Ляна и неинфекционной вершинной гнилью на обоих сортах, но не влияло на пораженность вредителями.

\section{Библиографический список}

1.Соколова Е.В., Мерзлякова В.М. Новые томаты для защищенного грунта // Гавриш. 2017. № 2. С. 32-37.

2.Лебедева М.А., Тунова Т.Н. Влияние сорта на продуктивность и качество плодов томата // Вестник Ижевской государственной сельскохозяйственной академии. 2013. № 3 (36). С. 98-100.

3.Коробейникова О.В. Фитоспорин-М на томате // Картофель и овощи. 2016. № 6. С. 16-17.

4.Доспехов Б.А. Планирование полевого опыта (с основами статистической обработки результатов исследований). М.: Агропромиздат, 1985. 351 с.

5.Государственный реестр селекционных достижений, допущенных к использованию (официальное издание) Т. 1: Сорта растений. М., 2010. 321 с.

6.Кульнев А.И., Соколова Е.А. Многоцелевые стимуляторы защитных реакций, роста и развития растений (на примере препарата иммуноцитофит). Пущино: ОНТИ ПНЦ РАИ, 1997.100 с.

7.Средство, проявляющее росторегулирующую и иммуномодулирующую активность.[Электронный ресурc]. URL: http://www.freepatent.ru/patents/2513621. (Дата обращения 30.01.2017).

8.Коробейникова О.В. Влияние обработки семян регуляторами роста растений на пораженность болезнями и урожайность яровых зерновых культур // Образование, наука и производство. 2015. № 3 (12). С. 54-56. Федотова С.Л., Кравченко А.В., Тимошина Н.А. Применение регуляторов роста на основе арахидоновой кислоты на картофеле // Защита и карантин растений. 2011. № 11. С. 18-19.

9.Список пестицидов и агрохимикатов, разрешенных к применению на территории Российской Федерации в 2012 году. Справочное издание. Приложение к жур налу «Защита и карантин растений». 2012. № 4.580 с.

\section{Об авторах}

Коробейникова Ольга

Валентиновна, канд. с. - х. наук, доцент кафедры земледелия и землеустройства

E-mail: korobejnikova.olga@inbox.ru Мерзлякова Вера Михайловна, канд. с. - х наук, доцент кафедры химии. E-mail: rector@izhgsha.ru ФГБОУ ВО Ижевская ГСХА

Immunitsitofit on tomatoes in open field O.V. Korobejnikova, $P h D$, associate

professor, department of agricultural and land management.

E-mail: korobejnikova.olga@inbox.ru V.M. Merzlyakova, $P h D$, associate professor, department of chemistry. E-mail: rector@izhgsha.ru

Izhevsk State Agricultural Academy

Summary. In the conditions of the Udmurt Republic studied the effect of spraying tomato plant with growth regulator Immunotsitofit on yield and diseases symptoms. As a result the yield of tomato varieties Liang and Grotto has increased. Spraying with Immunotsitofit significantly reduced tomato apical rot and late blight.

Keywords: tomato, open ground, determinate varieties, Liang, Grotto, plant growth regulators, Immunotsitofit, yield diseased noninfectious apical rot, late blight. 